\title{
Lysophosphatidic acid enhances human umbilical cord mesenchymal stem cell viability without differentiation via LPA receptor mediating manner
}

\author{
Narengerile $\mathrm{Li}^{1,2} \cdot$ Ya-Li Yan ${ }^{1}$ Sachaofu Fu ${ }^{1} \cdot$ Rui-Juan $\mathrm{Li}^{1} \cdot$ Peng-Fei Zhao ${ }^{1}$. \\ $\mathrm{Xi}$-Yuan $\mathrm{Xu}^{2} \cdot$ Jing-Ping Yang ${ }^{2}$ - Alatangaole Damirin ${ }^{1}$
}

Published online: 1 August 2017

(c) The Author(s) 2017. This article is an open access publication

\begin{abstract}
Human umbilical cord mesenchymal stem cells (hUC-MSCs) are potential stromal cells which are regarded as the most feasible stem cell group in cell therapy. The maintenance of cell survival without differentiation is important in cell transplantation and stem cell therapy. However, negative factors exist in cell transplantation. Lysophosphatidic acid (LPA) is a non-antigenic small molecule phospholipid which induced several fundamental cellular responses, such as cell proliferation, apoptosis and migration. In this study we aimed to explore the effects of LPA on the survival and differentiation of MSCs and its availability in cell therapy. We found that LPA stimulated hUC-MSC proliferation and protected hUC-MSCs from lipopolysaccharide (LPS) induced apoptosis. We also observed that CD29, CD44, CD73, CD90 and CD105 were expressed, whereas CD34 and CD45 were not expressed in hUC-MSCs, and these makers have no change in LPA containing medium, which indicated that LPA accelerated the survival of hUC-MSCs in an undifferentiating status. We
\end{abstract}

Li Narengerile and Yan Ya-Li have contributed equally to this work.

Electronic supplementary material The online version of this article (doi:10.1007/s10495-017-1399-6) contains supplementary material, which is available to authorized users.

Jing-Ping Yang

yangron@sina.com.cn

$\triangle$ Alatangaole Damirin

bigaole@imu.edu.cn

Department of Biology, College of Life Sciences, Inner Mongolia University, Hohhot 010021, Inner Mongolia, China

2 Department of Respiratory and Critical Medicine, The Third Affiliated Hospital, Inner Mongolia Medical University, Baotou 014010, Inner Mongolia, China also demonstrated that higher expressed LPAR1 involved in LPA stimulated cell survival action. LPA stimulated cell proliferation was associated with LPAR1 mediated $\mathrm{G}_{\mathrm{i} / \mathrm{o}}$-proteins/ERK1/2 pathway. On the other hand, LPA protected hUC-MSCs from LPS-induced apoptosis through suppressing caspase-3 activation by LPAR1 coupled with a $\mathrm{G}$ protein, but not $\mathrm{G}_{\mathrm{i} / \mathrm{o}}$ or $\mathrm{G}_{\mathrm{q} / 11}$ in hUC-MSC. Collectively, this study demonstrated that LPA increased the proliferation and survival of hUC-MSCs without differentiation through LPAR1 mediated manner. Our findings provide that LPA as a anti-apoptotic agent having potential application prospect in cell transplantation and stem cell therapy.

Keywords Lysophosphatidic acid · Human umbilical cord mesenchymal stem cells · Cell survival · Cell-surface marker $\cdot$ Receptor mediated signaling

$\begin{array}{ll}\text { Abbreviations } \\ \text { APS } & \text { Ammonium persulfate } \\ \text { CD } & \text { Cluster of differentiation } \\ \text { DEPC } & \text { Diethyl pyrocarbonate } \\ \text { Edg } & \text { Endothelial differentiation gene } \\ \text { EGF } & \text { Epidermal growth factor } \\ \text { ERK1/2 } & \text { Extracellular signal-regulated kinase 1/2 } \\ \text { FGF } & \text { Fibroblast growth factor } \\ \text { GPCR } & \text { G-protein coupled receptor } \\ \text { hUC-MSCs } & \text { Human umbilical cord mesenchymal stem } \\ & \text { cells } \\ \text { LPA } & \text { Lysophosphatidic acid } \\ \text { LPS } & \text { Lipopolysaccharide } \\ \text { MAPK } & \text { Mitogen activated protein kinase } \\ \text { MTT } & \text { 3-(4,5)-Dimethylthiahiazo(-z-y1)-3,5-diphe- } \\ & \text { nytetrazoliumromide } \\ \text { NC } & \text { Negative control } \\ \text { PDGF } & \text { Platelet derived growth factor }\end{array}$




\section{PTX Pertussis toxin \\ siRNA Small interfering RNA \\ TEMED Tetramethylethylenediamine}

\section{Introduction}

The maintenance and repair of adult tissues and organ are guaranteed by the adult stem cell pool. Among adult stem cells, mesenchymal stem cells (MSCs) are emerging as hopeful candidates for cell-based therapy of numerous diseases [1]. As a class of multi-potent adult stromal cell, MSCs are capable of self-renewal and multi-lineage differentiation into various tissues of mesodermal origin $[2,3]$. It was shown that MSCs not only engraft and differentiate into cardiomyocytes, but also stimulate the proliferation and differentiation of endogenous cardiac stem cells, and the proliferation of endothelial progenitor cells, improving normal endothelial function [4]. After in vitro culture expansion, MSCs are characterized by their capability to adhere to plastic, develop as fibroblast colony-forming-units, and differentiate into osteocytes, chondrocytes, and adipocytes, which are positive for CD73, CD90, and CD105 and negative for CD11b, CD14, CD34, CD45, and HLA-DR [5, 6]. MSCs can be easily isolated and expanded ex vivo from a wide range of adult and perinatal tissue such as the cord blood and Wharton jelly of the umbilical cord. In particular, the human umbilical cord mesenchymal stem cells (hUC-MSCs) are noninvasive and non-hematopoietic cells without ethical concerns when the cord is clamped [7]. The cell therapy protocols generally require hundreds of million hMSCs per treatment and, consequently, these cells need to be expanded in vitro for about 10 weeks before implantation [1]. However, hUC-MSCs, as all cultured primary cells, do not grown infinitely, but undergo only a limited number of cell division [8], and easily differentiate in vitro condition. The more important fact is that $5-25 \%$ of all injected stem cells are apoptotic [9].

Our previous study showed that lipoprotein-associated Lysophosphatidic acid (LPA) plays an important role in DNA synthesis and migration in human coronary artery smooth muscle cells $[10,11]$. LPA is a small glycerophospholipid (molecular weight: 430-480 Da) which is present in all eukaryotic tissues at low concentrations and can be detected in high nanomolar to low micromolar concentrations in the blood and lymph [12-15]. As one of the lipids, LPA performs several major functions in the body. As an intercellular signalling molecule, LPA directly exerts functions through cognate $G$ protein-coupled receptors (GPCRs) and intracellular second messenger systems of individual cells and tissues [16-18]. LPA is involved in the regulation of fundamental cellular functions including cell proliferation, differentiation, migration, adhesion, morphogenesis, cytoskeletal changes and calcium influx [19-22]. Moreover, LPA plays a fundamental role in normal physiological processes and diseases, including nervous system functions, vascular development, immune system functions, cancer progression, reproduction, fibrosis, obesity and gastrointestinal and cardiovascular systems functions [23, 24].

Most biological functions of LPA are mediated by specific interactions with its five or more cognate receptors, known as LPA receptors (LPARs), on plasma membranes [25-29]. LPAR1/Edg-2, LPAR2/Edg-4 and LPAR3/Edg-7 belong to the endothelial differentiation gene (Edg) family of receptors and present about $55 \%$ sequence identity [12, 25, 26]. LPAR4-6 is structurally distinct from Edg receptors sharing significant homology and is closely related to P2Y purinergic receptors. These receptors, which consist of seven putative transmembrane domains, couple with and activate various $G$ proteins, including $G_{\alpha i / o}, G_{\alpha q / 11}, G_{\alpha 12 / 13}$ and $G_{\alpha \mathrm{s}}[23,30,31]$. Given the heterogeneity of receptor subtypes, expression patterns and effector pathways, the regulatory effects of LPA on biological processes are diverse and widespread. The initial foci of LPAR studies were on the vascular or nervous systems. However, these receptors also show applications in stem cell biology. In the current study, we detected the expression of LPA receptors in hUC-MSCs, explored the effects of LPA on the survival and differentiation of hUC-MSCs and elucidated the underlying mechanisms.

\section{Materials and methods}

\section{Materials}

1-Oleoyl-sn-glycero-3-phosphate (LPA), fatty acid-free BSA, pertussis toxin (PTX), PDGF, Ki-16425 and PD98059 were obtained from Sigma-Aldrich Co. LLC. MK-2206 and SB203580 were purchased from Selleck Chemicals. The p-ERK1/2 and ERK1/2 antibodies were purchased from Cell Signaling. YM-254890 was generously provide by Prof. Fumikazu Okajima (Gunma University, Japan). The sources of all other reagents were described in supporting information for detailed descriptions.

\section{Isolation and culture of hUC-MSCs}

Human umbilical cords were supplied from volunteers of the Third Affiliated Hospital of Inner Mongolia Medical University. Fresh umbilical cords were washed with phosphate-buffered saline (PBS). Blood vessels were removed before cutting up into gruel. Small pieces of tissues were arranged from the inside of a culture bottle with $10 \mathrm{~mL}$ of Dulbecco's modified Eagle's medium (DMEM-F12, 
Gibco) supplemented with $10 \%$ (v/v) foetal bovine serum (HyClone), $0.5 \mathrm{ng} / \mathrm{mL}$ human epidermal growth factor (Promega), $2 \mathrm{ng} / \mathrm{mL}$ human fibroblast growth factor-2 (Promega) and 100 units $/ \mathrm{mL}$ penicillin/streptomycin in a humidified (air/ $\left.\mathrm{CO}_{2} 19: 1\right)$ atmosphere for $4 \mathrm{~h}$ at $37^{\circ} \mathrm{C}$. The medium was replaced with $15 \mathrm{~mL}$ of new medium after 7 days; The medium was replaced every 7 days. Adherent cells were identified by flow cytometry to test the specific cell surface markers of MSCs. Cells with four to eight passages were used in the present study and switched to serumfree medium containing $0.1 \%(\mathrm{w} / \mathrm{v})$ fatty-acid-free bovine serum albumin (BSA) at $12 \mathrm{~h}$ before the experiments.

\section{Quantitative RT-PCR analysis}

The total RNA was extracted from hUC-MSCs by using TRIzol reagent (Takara). One microgram of the total RNA was used to reverse transcription reaction by using PrimeScript ${ }^{\circledR}$ RT reagent Kit after removing the genomic DNA through gDNA Eraser (Perfect Real Time, Takara). Quantitative real-time PCR was performed with SYBR $^{\circledR}$ Premix Ex Taq $^{\text {TM }}$ II (Tli RNaseH Plus, Takara) in LightCycler ${ }^{\circledR} 480$ (Roche). The expression level of the target mRNA was normalised to the relative ratio of the expression of GAPDH and beta-actin. Each RT-PCR assay was conducted following the manufacturer's instructions and applied at least thrice. The primers used for qPCR are listed in Online Resource 1, which are synthesized by Sangon Biotech (Shanghai).

\section{Cell viability assay}

Cell viability was tested by TransDetect TM Cell Counting Kit (CCK, TransGen Biotech) and cell proliferation ELISA kit (BrdU, colorimetric, Roche). Cells were seeded in 24-well plates and stimulated with different reagents for $24 \mathrm{~h}$. CCK was added to each well at a final concentration of $10 \%$ and then incubated for $2 \mathrm{~h}$. Quantitative colorimetric assay at $450 \mathrm{~nm}$ was performed on a 96-well scanning spectrophotometer.

For BrdU assay, cells were seeded in 96-well plates with a final volume of $100 \mu \mathrm{L} /$ well. After an appropriate incubation time, the assay was performed following the manufacturer's instructions. Cells were added to $10 \mu \mathrm{L} /$ well $\mathrm{BrdU}$ labelling solution and then re-incubated for $2 \mathrm{~h}$ at $37^{\circ} \mathrm{C}$. Two-hundred $\mu \mathrm{L} /$ well FixDenat was added to the cells after removal of labelling medium and then incubated for $30 \mathrm{~min}$ at +15 to $+25^{\circ} \mathrm{C}$. After removal of FixDenat solution, $100 \mu \mathrm{L} /$ well anti-BrdU-POD working solution was added to the plates, and the mixture was incubated for $90 \mathrm{~min}$ at +15 to $+25^{\circ} \mathrm{C}$. Antibody conjugate was removed, and the wells were rinsed thrice with $200 \mu \mathrm{L} /$ well washing solution (1× PBS). After removal of the washing solution, $100 \mu \mathrm{L} /$ well substrate solution was added, and the mixture was incubated for $8 \mathrm{~min}$ at +15 to $+25^{\circ} \mathrm{C}$. Twenty-five $\mu \mathrm{L} /$ well $1 \mathrm{M} \mathrm{H}_{2} \mathrm{SO}_{4}$ was then added, and the mixture was incubated for $1 \mathrm{~min}$ on a shaker at $300 \mathrm{rpm}$. The absorbance of the samples was measured immediately at $450 \mathrm{~nm}$ (reference wavelength: $690 \mathrm{~nm}$ ) by Epoch (BioTek, USA).

\section{Transfection of small interfering RNA}

The cells were plated on 24 multiplates at $2 \times 10^{5}$ cells/ well. Small interfering RNAs (siRNAs, $50 \mathrm{nM}$ ) were introduced into cells using Lipofectamine 2000 reagent (Invitrogen) according to the manufacturer's instructions. The total RNA was extracted from cells after cultured for $24 \mathrm{~h}$. The mRNA levels of LPAR1 and S1PR1 were measured using real-time SYBR Green technology. For the BrdU assay, cells were plated on 96 multiplates at $2 \times 10^{5}$ cells/ well and transfected with $50 \mathrm{nM}$ siRNAs for $48 \mathrm{~h}$ after cell attachment. Cells were stimulated with different reagents for $24 \mathrm{~h}$ and detected by BrdU kit after serum starvation as described. The nonsilencing siRNA (NC) and siRNA specific to LPAR1 (M-003952-00) were obtained from Sangon Biotech (Shanghai).

\section{Caspase-activity assay}

For lipopolysaccharide (LPS, Biotopped) induced apoptotic experiment, the cells were exposed to different conditions in 10\% FBS medium, which contains LPS binding protein.

The cells were seeded in 96-well plates with a final volume of $100 \mu \mathrm{L} /$ well. After an appropriate incubation time, the assay was performed following the manufacturer's instructions. Apo-ONE ${ }^{\circledR}$ Homogeneous Caspase-3(7)/8/9 Reagent (Promega) was added at $100 \mu \mathrm{L} / \mathrm{well}$, and the mixture was incubated for $2.5 \mathrm{~h}$ at +15 to $+25^{\circ} \mathrm{C}(1 \mathrm{~min}$ on a shaker at $300 \mathrm{rpm})$. The absorbance of the samples was measured at an excitation wavelength of $485 \mathrm{~nm}$ and an emission wavelength of $530 \mathrm{~nm}$ by Varioskan Flash (Thermo Scientific, USA).

\section{Assessment of morphological changes by fluorescence microscopy}

Chromosomal condensation was assessed using the chromatin dye Hoechst33342 (Beyotime Institute of Biotechnology, China). HUC-MSCs were fixed for $10 \mathrm{~min}$ in PBS containing $1 \%$ paraformaldehyde at +15 to $+25^{\circ} \mathrm{C}$. After fixing, the cells were washed twice with PBS and then exposed to $10 \mu \mathrm{g} / \mathrm{mL}$ Hoechst 33342 in PBS for $30 \mathrm{~min}$ at +15 to $+25^{\circ} \mathrm{C}$. All samples were observed under a fluorescence microscope. Apoptotic cells were characterised by morphological alterations such as condensed nuclei and cell shrinkage. 


\section{Flow cytometry analysis of cell surface markers}

Approximately $2 \times 10^{5}$ cells were seeded in six-well plates for $24 \mathrm{~h}$. Flow cytometry was used to detect cell surface markers after LPA stimulation for $72 \mathrm{~h}$. The cells were collected and washed with PBS containing 0.5\% BSA (FACS buffer) and then incubated with $20 \mu \mathrm{L}$ each of CD34-PE, CD90-FITC, CD29-APC, CD105-PerCP, CD44-PE, CD45FITC, CD73-PE and CD71-FITC mouse anti-human monoclonal antibody (Becton Dickinson, USA) in a total volume of $100 \mu \mathrm{L}$ for $20 \mathrm{~min}$ at +15 to $+25^{\circ} \mathrm{C}$ in dark place. The cells were pelleted and then washed thrice in FACS buffer. The cells were then fixed with $2 \%$ paraformaldehyde in FACS buffer and subjected to flow cytometry on a FACScan flow cytometer (Becton Dickinson, USA).

\section{Western blot assay for ERK1/2 activation}

HUC-MSCs were seeded in $60 \mathrm{~mm}$ dish and then starved for $6 \mathrm{~h}$ in serum-free medium. The cells were washed twice with ice-cold PBS and then lysed with ice-cold RIPA buffer (Solarbio, China). The cell lysate was centrifuged at $14,000 \times g$ for $10 \mathrm{~min}$ at $4{ }^{\circ} \mathrm{C}$ and the protein concentration was determined by the BCA assay. Equal amounts of protein were separated on $10 \%$ SDS-PAGE gels by electrophoresis, then transferred to PVDF membranes using semi-dry electroblotting apparatus. The membranes were blocked for $2 \mathrm{~h}$ at room temperature in 5\% skim milk, then incubated with primary antibody in $2 \%$ skim milk over night at $4{ }^{\circ} \mathrm{C}$ and secondary antibody in $5 \%$ skim milk for $2 \mathrm{~h}$ at room temperature.

\section{Data analysis}

The mean values of the different groups were showed as mean \pm SD. All statistical comparisons were performed using one-way ANOVA followed by Bonferroni's post-hoc test for multi-group comparisons in GraphPad Prism version 5.01 (GraphPad Software, San Diego, CA). Statistical significance was assessed by Student's $t$ test, and the values were considered significant at $p<0.05$. Statistical significance is designated as asterisk in the figure legends.

\section{Results}

\section{LPA enhanced hUC-MSCs survival through proliferation and anti-apoptotic action}

To explore the availability of LPA in cell therapy, we first examined the ability of LPA to stimulate the proliferation of hUC-MSCs by CCK kit. As shown in Fig. 1a, cell numbers were increased by LPA stimulation in a dosedependent manner with a peak at $0.1-1 \mu \mathrm{M}$. Meanwhile, we also found that LPA induced a significantly increasing DNA synthesis since $12 \mathrm{~h}$ and a peak at $24 \mathrm{~h}$, when detected by BrdU assay (Fig. 1b).

We wondered if the increasing cell number response to LPA are due to the proliferation and anti-apoptotic action. Therefore we performed lipopolysaccharide (LPS) induced apoptosis experiments. As shown in Fig. 2a, cells were incubated with LPS $(0.1,1,10$ and $20 \mu \mathrm{g} / \mathrm{mL})$ in $10 \%$ FBS containing medium for $24 \mathrm{~h}$ before determining caspase- 3 activity, and $10 \mu \mathrm{g} / \mathrm{mL}$ LPS was selected as the optimum dose for the apoptotic experiment. The caspase-3 activity response to LPS was completely inhibited by LPA at $1 \mu \mathrm{M}$ (Fig. 2b). In parallel, cell death was determined morphologically, as shown in Fig. 2c. The control cells exhibited a normal elongated MSC morphology with large regular nuclei. After LPS treatment with $1 \mu \mathrm{M}$ LPA, clear apoptotic characteristics of shrinkage in cell size and cell loss together with clear chromatin condensation and typical fragmented nuclei were observed. LPA efficiently blocked apoptosis with cells maintaining their elongated morphology and large nuclei. Ac-DEVDCHO and Z-VAD-FMK are the selective inhibitor of caspase-3. Therefore, we attempted to confirm the inhibition of caspase-3 activity response to LPA using Ac-DEVDCHO and Z-VAD-FMK. As shown in Fig. 2d, LPA suppressed LPS induced caspase- 3 activity y about $60 \%$ and the inhibitory effect was the same as Z-VAD-FMK. These results suggest that anti-apoptotic action in respose to LPA is mediated by suppressing caspase- 3 activation in hUC-MSCs.

\section{LPA had no effect on the expression of cell surface markers of hUC-MSCs}

The International Society for Cellular Therapy (ISCT) has proposed a set of standards to define MSCs. A cell can be classified as an MSC if it shows plastic adherent properties under normal culture conditions and exhibits a fibroblast-like morphology. Cultured MSCs also express CD73, CD90 and CD105 on their surface but do not express CD11b, CD14, CD19, CD34, CD45, CD79a and HLA-DR [5]. Therefore, we investigated whether LPA can induce the differentiation of hUC-MSCs. As shown in Fig. 3 and Online Resource 2, hUC-MSCs express mRNAs of CD29, CD34, CD44, CD45, CD71, CD73, CD90 and CD105. The expression pattern of these cell surface markers have no change in hUC-MSCs cultured in with or without LPA stimulation. 
Fig. 1 LPA increased the proliferation of hUC-MSCs. a CCK kit was used to determine the cells proliferation after LPA treated with a various concentrations $(0.01,0.1,1,10$ and $15 \mu \mathrm{M}$ ) for $24 \mathrm{~h}$. b HUCMSCs in 96-multiplates were stimulated with $1 \mu \mathrm{M}$ LPA for different time, then measured by BrdU assay. Absorbance was read at $450 \mathrm{~nm}(690 \mathrm{~nm}$ as reference) to determine cell proliferation. The asterisk (*) indicates that the effects were significant. Values are means \pm SD and represent three independent experiments $(* \mathrm{p} \leq 0.05, * * \mathrm{p} \leq 0.01$ and $* * * \mathrm{p} \leq 0.001)$

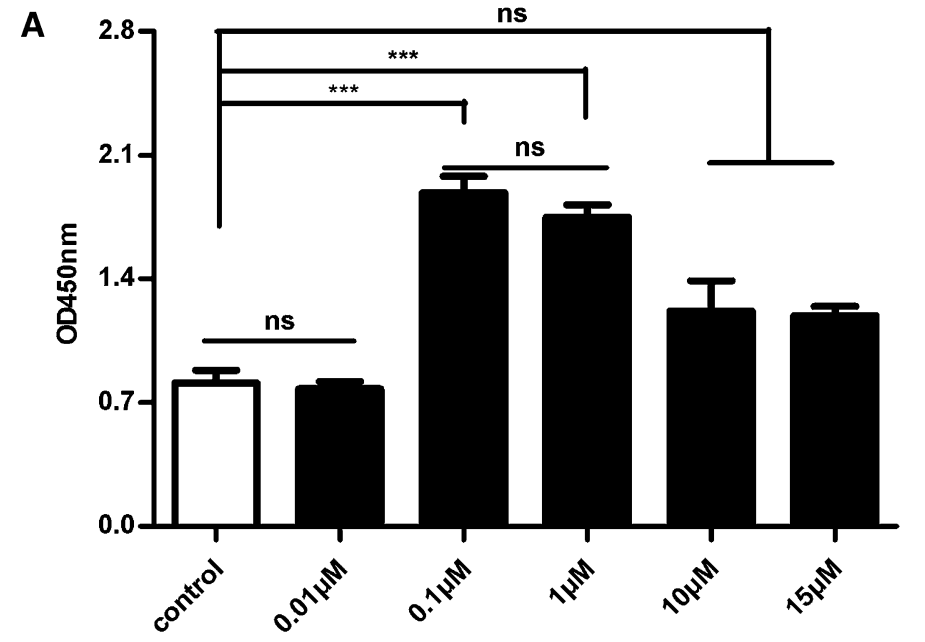

LPA Concentration

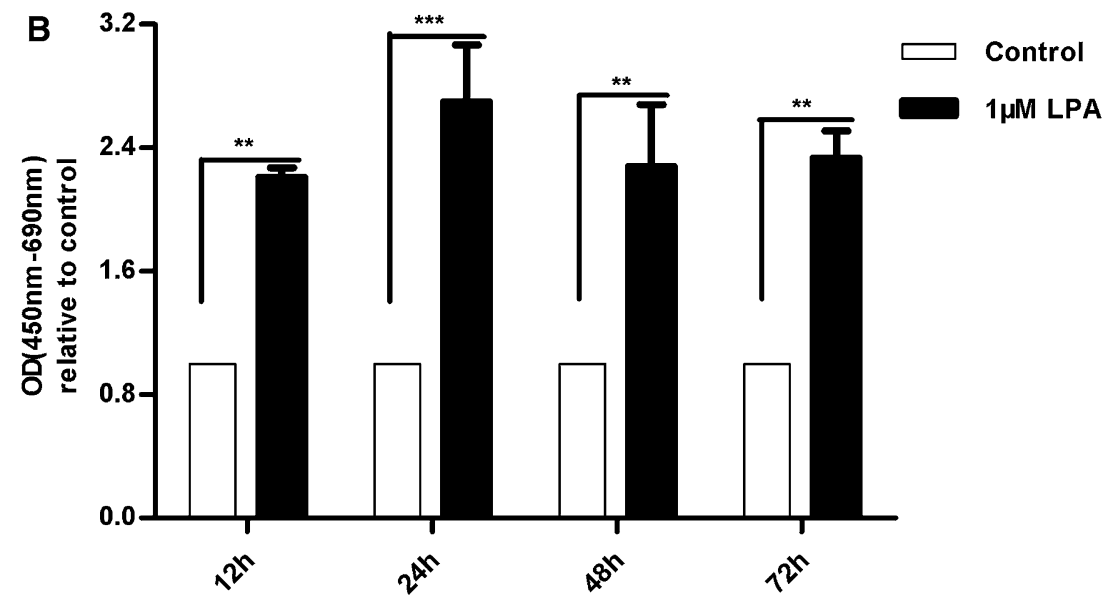

LPA stimulated hUC-MSCs proliferation was mediated by LPAR1/G $G_{i / o}$ and $G_{q / 11}$-protein/ERK1/2 pathway

In order to clarify LPA receptor subtypes involved in the proliferation response, we examined the expression patterns of LPA receptor mRNA in hUC-MSCs. Among the LPA receptor subtypes, LPAR1 mRNA is expressed at an extremely high level, supporting the possible role of LPAR1 in the LPA induced proliferation (Fig. 4a). As shown in Fig. 1c, LPA stimulated proliferation was almost completely inhibited by Ki16425, an LPAR1- and LPAR3specific antagonist. Ki16425 did not affect the PDGFinduced proliferation, indicating the specificity of the agent (Fig. 4b). To confirm the involvement of LPAR1 in LPA induced action, siRNA specific to LPAR1 was employed. We found that the siRNA inhibited LPAR 1 mRNA expression without having any significant effect on the mRNA expression of S1P1 receptor, which also belong to the Edg family of receptors (Fig. 4c, d). Under the conditions, siRNA specific to LPAR1 markedly inhibited the stimulated proliferation response to LPA (Fig. 4e). The results suggest that LPAR1 mediate the LPA-induced proliferation response in hUC-MSCs.

Based on our current results described above, we were to further research the mechanisms of LPA induced proliferation of hUC-MSCs. LPAR1 are reported to be coupled to $\mathrm{G}_{\mathrm{i} / \mathrm{o}}$-proteins and $\mathrm{G}_{\mathrm{q} / 11}$-proteins [18], we examined whether G-proteins involved in LPA induced proliferation by using inhibitors. As shown in Fig. 4a, LPA stimulated proliferation was almost completely inhibited by pertussis toxin (PTX), a specific inhibitor of $\mathrm{G}_{\mathrm{i} / \mathrm{o}}$-proteins. PTX did not affect the PDGF-induced action (Fig. 4f). These results suggest that LPA stimulated proliferation through $\mathrm{G}_{\mathrm{i} / \mathrm{o}}$-protein-coupled LPAR1 receptor in hUC-MSCs. By way of BrdU ELISA assay with inhibitors, we also found that YM254890, a specific inhibitor of $\mathrm{G}_{\mathrm{q} / 11}$-proteins, has slightly effects on the LPA action (Fig. 4g). Meanwhile, LPA stimulated proliferation was also almost completely inhibited by PD98059, an inhibitor of ERK1/2, which did not affect the PDGF-induced action (Fig. 4h).

LPA induced ERK1/2 phosphorylation shown a timedependent with a peak at $5 \mathrm{~min}$ in hUC-MSCs (Fig. 5a). 

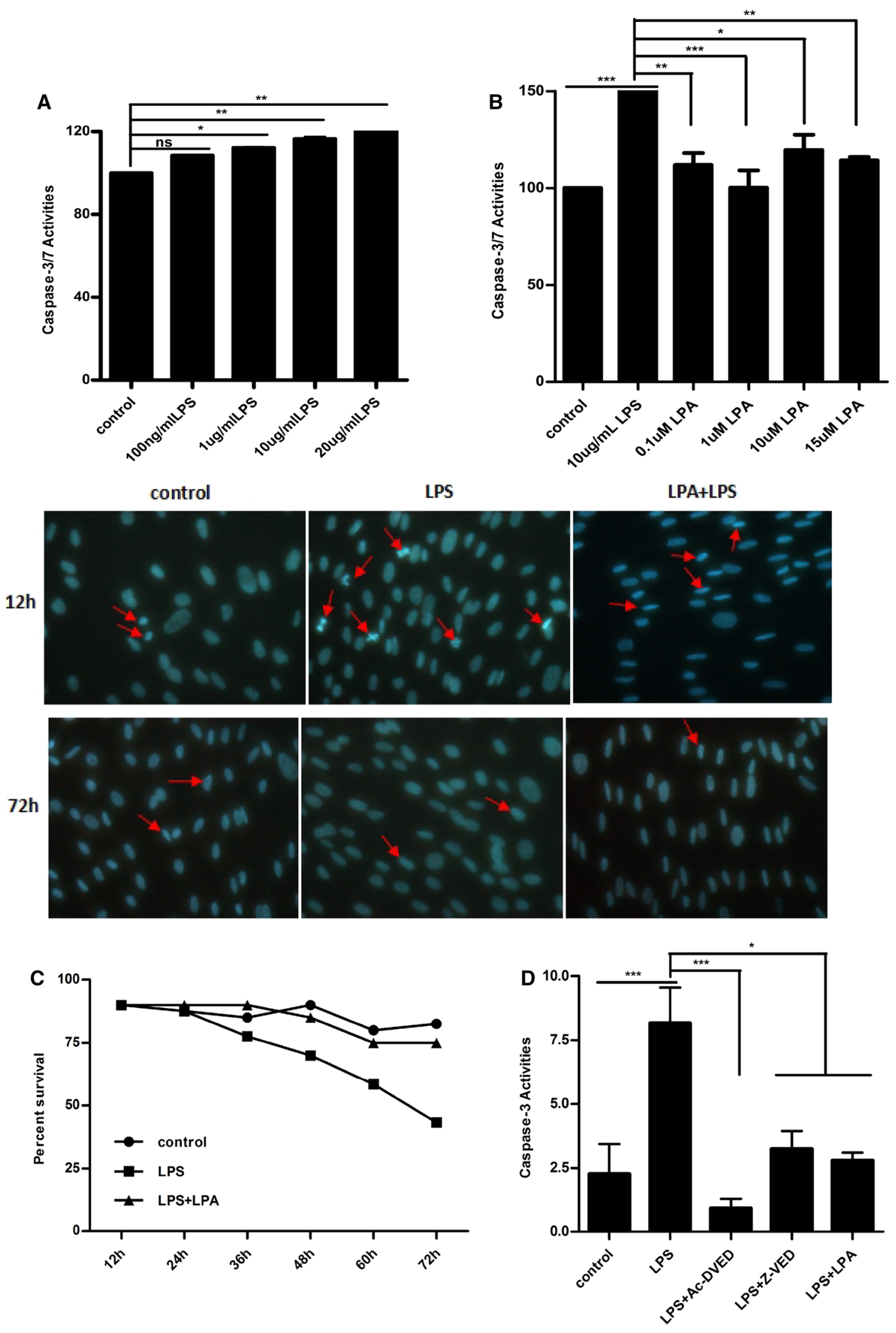
4Fig. 2 LPA protected hUC-MSCs from LPS-induced apoptosis. a HUC-MSCs in 96-multiplates were incubated with various concentrations of LPS for $24 \mathrm{~h}$ in an antibiotic-free culture medium with $10 \%$ FBS. The caspase-3 activity was examined by Apo-ONE ${ }^{\circledR}$ Homogeneous caspase-3/7 Assay. b The cells were incubated with various concentrations of LPA and $10 \mu \mathrm{g} / \mathrm{mL}$ LPS for $48 \mathrm{~h}$ and the caspase-3/7 activity was detected. c HUC-MSCs in 24-multiplates were incubated with $1 \mu \mathrm{M} \mathrm{LPA}$ and $10 \mu \mathrm{g} / \mathrm{mL}$ LPS at indicated time, and stained in $10 \mu \mathrm{g} / \mathrm{mL}$ Hoechst 33342 in PBS for $30 \mathrm{~min}$. After fixing with $1 \%$ paraformaldehyde for $10 \mathrm{~min}$. The images of cells were captured using a fluorescence microscope. d HUC-MSCs in 96-multiplates were stimulated with different condition $(10 \mu \mathrm{g} / \mathrm{mL}$ LPS, $1 \mu \mathrm{M}$ LPA, $100 \mathrm{nM}$ caspase-3 inhibitor Ac-DEVD-CHO and $10 \mu \mathrm{M}$ caspase inhibitor Z-VAD-FMK) for $24 \mathrm{~h}$ in antibiotic free culture medium included $10 \%$ FBS. The caspase- 3 activity was detected by Apo-ONE ${ }^{\circledR}$ homogeneous caspase- $3 / 7$ assay. Values are means $\pm \mathrm{SD}$ and represent three independent experiments $(* \mathrm{p} \leq 0.05, * * \mathrm{p} \leq 0.01$ and $* * * \mathrm{p} \leq 0.001)$

LPA induced ERK1/2 phosphorylation was inhibited by Ki16425 and YM254890 treatment (Fig. 5b). As shown in Fig. 5c, LPA stimulated ERK1/2 phosphorylation was markedly inhibited when cells were pre-treated with PTX for $16 \mathrm{~h}$ and PD98059 for $30 \mathrm{~min}$ in hUC-MSCs, suggesting that LPA/LPAR1-mediated proliferation in hUC-MSCs was dependent on PTX-sensitive $\mathrm{G}_{\mathrm{i} / \mathrm{o}}$ and $\mathrm{G}_{\mathrm{q} / 11}$ protein and ERK1/2 signalling pathways.

\section{LPA enhanced the survival of hUC-MSCs in a PTX-independent manner}

In order to examine the roles of LPA receptor subtypes in the anti-apoptitic action of LPA, Ki16425 was used. As shown in Fig. 6a, $10 \mu \mathrm{M}$ Ki16425 completely reversed LPA induced inhibitory action to caspase-3 activation. SiRNA specific to LPAR1 was used to confirm the involvement of LPAR1 in the action. LPA induced anti-apoptosis was inhibited by LPAR1 siRNA, suggesting LPAR1 mediate the LPA induced anti-apoptosis in hUC-MSCs (Fig. 6b). The further researches about the mechanism of LPA suppressed caspase-3 activity were employed with inhibitors. We found PTX (100 ng/mL) and YM254890 (100 nM) have no effect on LPA suppressed caspase-3 activity (Fig. 6b). Meanwhile, we also found that all inhibitors of PD98059 (an inhibitor of ERK1/2), MK-2206 (an inhibitor of Akt, Selleckchem) and SB203580 (an inhibitor of p38 MAP kinase) have no effect on LPA suppressed caspase-3 activity (Fig. 6c, d). These data indicated that LPA remarkably increased hUC-MSC survival through LPAR1/3 in a PTX-independent manner.

\section{LPA elicited anti-apoptotic effect by inhibiting caspase-3}

LPA promoted hUC-MSC survival by decreasing the activation of caspase-3. We finally examined both caspase- 8 and caspase-9 to determine which apoptotic signalling pathway is involved in the LPA-induced reduction of activated caspase-3. As shown in Fig. 7a, b, caspase-9 activity significantly increased after LPS-induced apoptosis with decreasing caspase- 8 activity. Interestingly, LPA did not affect caspase- 9 activity. These results indicated that LPS induced apoptosis through the Fas (cytochrome C/ caspase-9/caspase-3) pathway and that LPA decreased the activation of caspase-3 through LPAR1/3 in a PTX-independent manner to promote hUC-MSC survival.

\section{Discussion}

HUC-MSCs are potential stromal cells isolated from the umbilical cord and are regarded as the most feasible stem cell source for cell therapy. Umbilical cords can provide inexhaustible and inexpensive stem cell sources without invasive surgery and controversies [32]. HUC-MSCs are primitive MSCs which exhibit a high plasticity and developmental flexibility [33]. In the current study, hUC-MSCs were isolated effectively and used to detect cell surface markers by flow cytometry. However, hUC-MSCs and other stem cell applications still have several negative characteristics, such as easily differentiation or low survival. Therefore, to study on the development of bio-active reagents in order to improve stem cell survivability and maintain the cell keeping in undifferentiated state is very important, which have being a focus in field of cell therapy.

LPA, a pleiotropic lipid growth factor, induces many fundamental cellular responses, such as cell proliferation, apoptosis and migration through combination with GPCR LPAR1-6. In our previous study, we found that LPA/ LPA1 receptors mediate the DNA synthesis and migration response to LDL in coronary artery vascular smooth muscle cells [10, 11] and LPA/LPA2 receptors stimulates the migration of human gastric cancer cells (SGC-7901) [34]. LPA is a bioactive endogenous phospholipid without immunogenicity. LPARs are expressed in many types of cells, demonstrating a differential expression profile across various cells and tissues [35, 36]. LPA is also a proliferative survival factor in various stem cells. In the current study, we assessed the effect of LPA on the survival and differentiation of hUC-MSCs and its availability in cell therapy. We found that LPA stimulated hUC-MSC proliferation in a dose-dependent manner. Furthermore, we examined the inhibitory effects of LPA on LPS-induced hUC-MSC apoptosis. We found that LPA protected hUC-MSCs from LPS-induced apoptosis. The maintenance of cell survival without differentiation is essential in stem cell therapy. Thus, we examined the effects of LPA on the differentiation of hUC-MSCs through detection of cell surface markers. Flow cytometry demonstrated that CD29, CD44, CD73, 


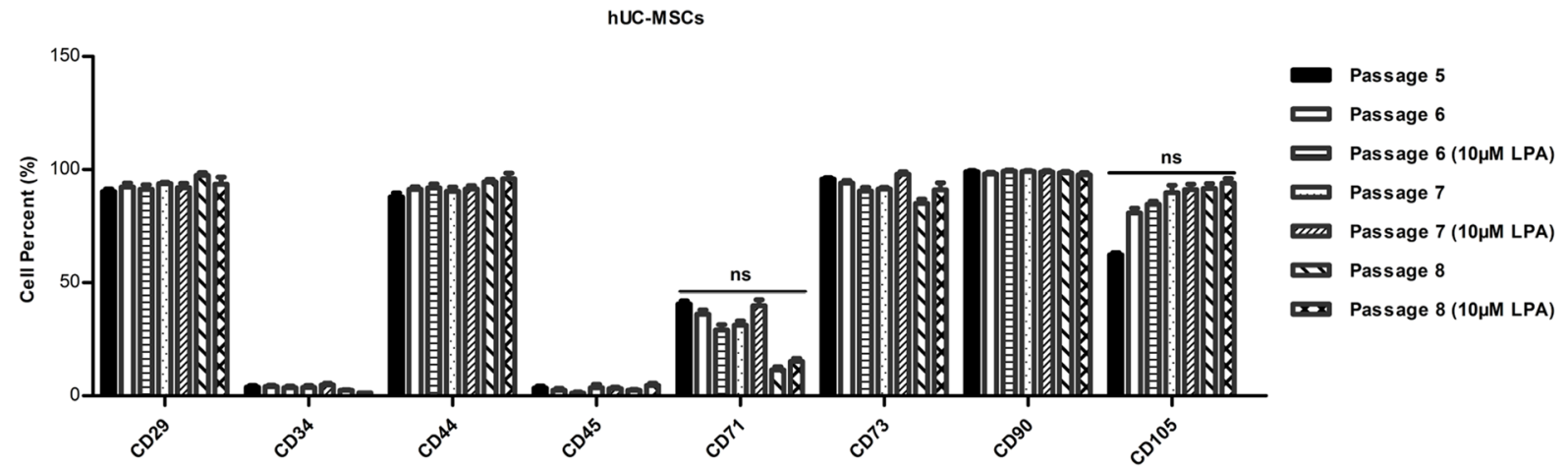

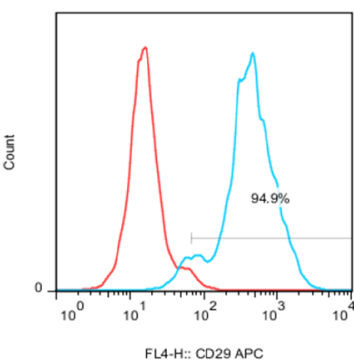
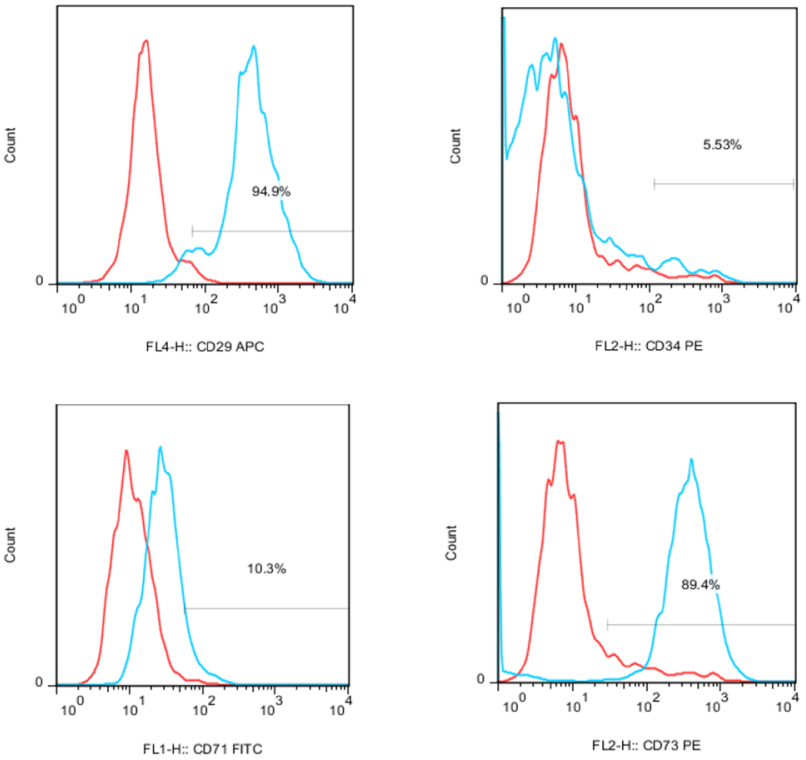

Fig. 3 LPA had no effect on the expression of cell surface markers of hUC-MSCs. Five to eight passages serum-starved hUC-MSCs were pretreated with or without $10 \mu \mathrm{M}$ LPA for $72 \mathrm{~h}$, and the cell surface markers were detected by flow cytometry. Each sample was mixed with $20 \mu \mathrm{L}$ of IgG1-FITC, IgG1-PE, IgG1-APC and IgG1-PerCP for the control. HUC-MSC specific surface markers $(20 \mu \mathrm{L})$, such

CD90 and CD105 were expressed in hUC-MSCs, whereas CD34 and CD45 were not expressed. The results accord with the standards of MSCs proposed by ISCT. Our results showed that hUC-MSCs were maintained undifferentiated stage for eight passages at LPA stimulated condition, suggesting LPA accelerated the proliferation and survival of hUC-MSCs without differentiation. Other investigations also has been reported that LPA is capable of preventing cell apoptosis of human neural progenitor cells [37], hippocampal progenitor cells H19-7 [38], mouse embryonic stem cell [39], human $\mathrm{CD}_{3} 4^{+}$cells [40] and human bone marrow-derived mesenchymal stromal cells [41]. LPA rescues $\mathrm{H}_{2} \mathrm{O}_{2}$-induced apoptosis mainly mediated by LPAR3 interacting with $\mathrm{G}_{\mathrm{i} / \mathrm{o}}$ protein and inhibition caspase-3 cleavage in bone marrow-derived mesenchymal stem cells [42].
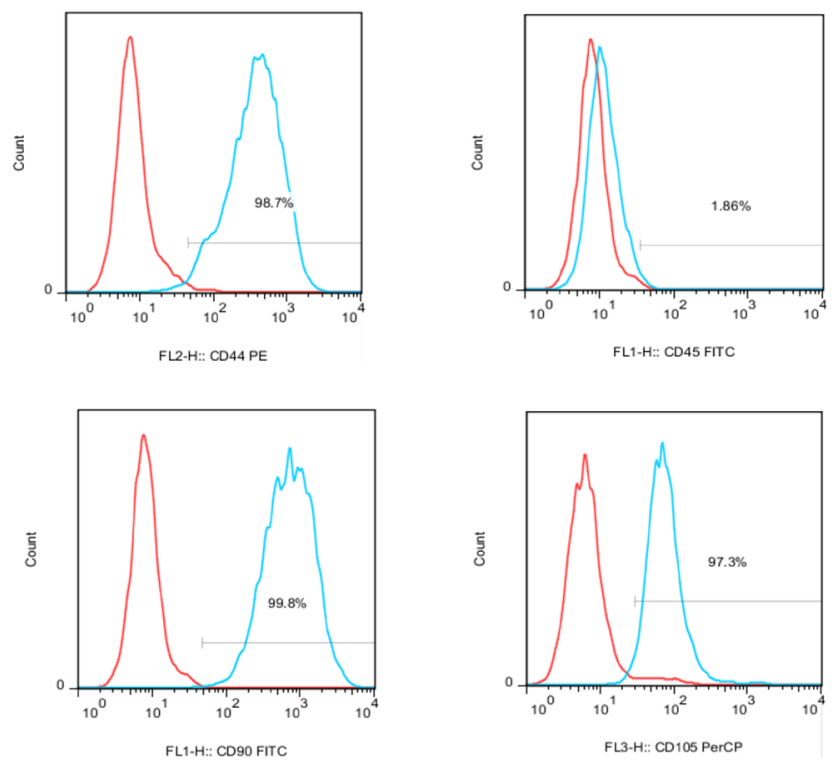

as CD90-FITC, CD29-APC, CD105-PerCP, CD44-PE, CD45-FITC, CD73-PE, CD34-PE and CD71-FITC were added to the samples to detect differentiation by flow cytometry. Values are means \pm SD and represent three independent experiments $(* \mathrm{p} \leq 0.05, * * \mathrm{p} \leq 0.01$ and $* * * \mathrm{p} \leq 0.001)$

We examined the expression patterns of LPA receptor mRNAs in hUC-MSCs. Among theses receptors LPAR1 mRNA expression level was higher than any other receptors, supporting the possible role of LPAR1 in LPA induced proliferation and anti-apoptotic effect. To confirm the involvement of LPAR1 in LPA induced action, siRNA specific to LPAR1 and Ki16425 (LPAR1/3 antagonist) weres employed. The LPA induced proliferation and anti-apoptotic action were completely inhibited by adding Ki16425. LPAR1-specific siRNA significantly suppressed the proliferation and anti-apoptosis response to LPA, suggesting that the effects of LPA on hUC-MSCs survival were mainly mediated by LPAR1.

LPA receptor subtypes are coupled to specific G protein and transfer various downstream cell signalling 

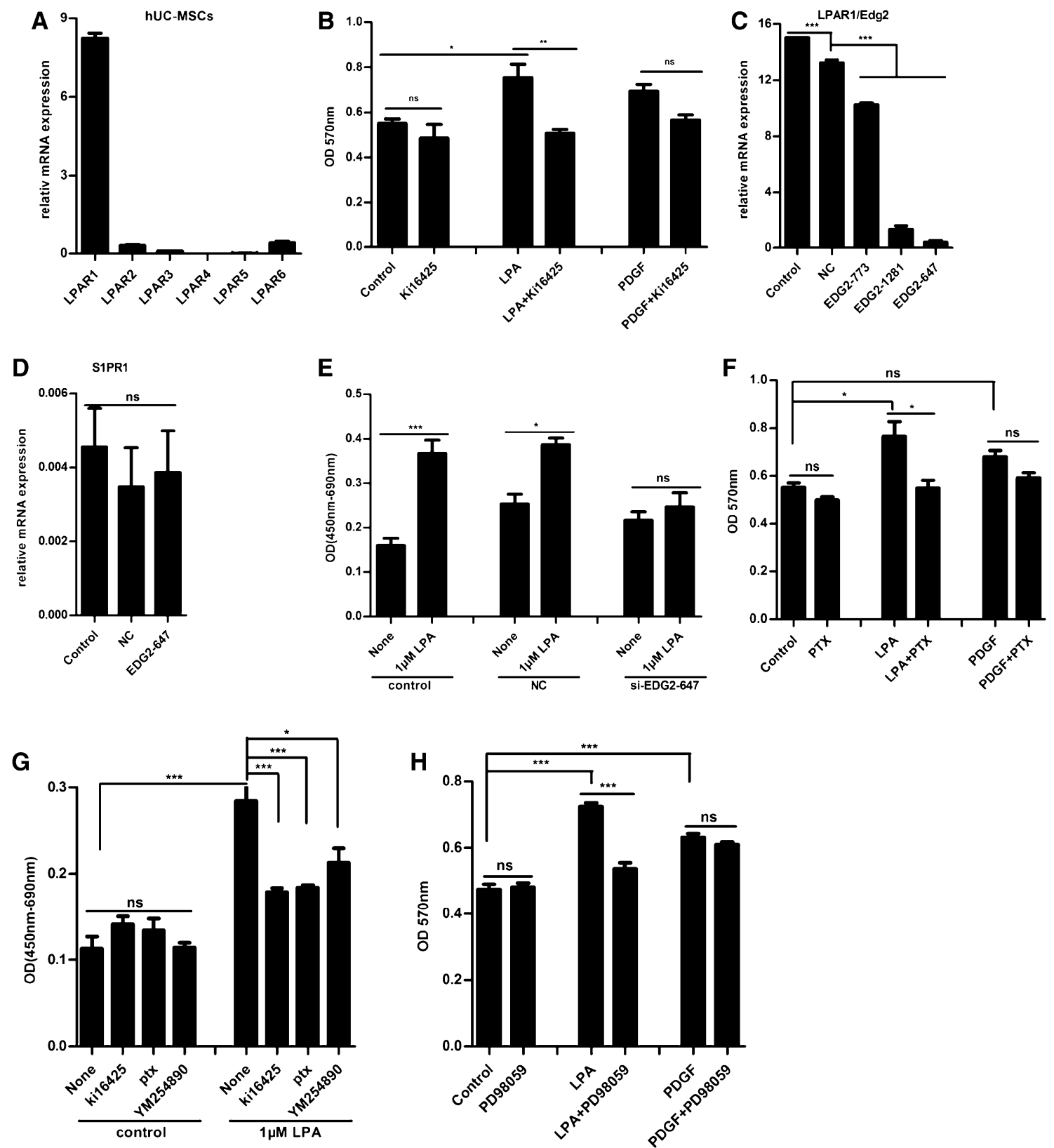

Fig. 4 LPA enhenced proliferation of hUC-MSCs mediated by LPAR 1 coupled to $\mathrm{G}_{\mathrm{i} / \mathrm{o}}$-protein. a mRNA expression of LPARs were detected by RT-PCR relative to GAPDH and beta-actin in hUCMSCs. LPAR1 mRNA was profoundly higher than any other receptors. b The cell growth in response to $1 \mu \mathrm{M}$ LPA was measured by MTT for $48 \mathrm{~h}$ with presence or absence of $10 \mu \mathrm{M}$ Ki16425 (an LPAR 1/3 antagonist) in hUC-MSCs. c, d HUC-MSCs in 24-multiplates were transfected with $50 \mathrm{nM}$ NC siRNA (negative control) or LPAR1-specific siRNA (EDG2-homo-1281, EDG2-homo-647, EDG2-homo-773) for $24 \mathrm{~h}$, then extracted total RNA. The mRNA for LPAR1 and S1PR1 in hUC-MSCs were assessed by real-time SYBR Green PCR. Results are showed as the relative ratios to GAPDH and $\beta$-actin mRNA expression. e HUC-MSCs in 96-multiplates were stimulated with $1 \mu \mathrm{M}$ LPA for $24 \mathrm{~h}$ after transfected with $50 \mathrm{nM}$ NC siRNA (negative control) or LPAR1-specific siRNA EDG2-homo-647 for $48 \mathrm{~h}$. The cell proliferation was measured by
BrdU assay. Absorbance was read at $450 \mathrm{~nm}$ (690 $\mathrm{nm}$ as reference) to determine cell proliferation. f HUC-MSCs in 24-multiplates were incubated with $10 \mu \mathrm{M}$ LPA or $10 \mathrm{ng} / \mathrm{mL}$ PDGF for $48 \mathrm{~h}$ by MTT after pretreated with the indicated inhibitors. The cells were pretreated with $100 \mathrm{ng} / \mathrm{mL}$ PTX (pertussis toxin, an inhibitor of $\mathrm{G}_{\mathrm{i} / \mathrm{o}}$-protein coupled receptors) for $16 \mathrm{~h}$. g HUC-MSCs in 96-multiplates were stimulated with $10 \mu \mathrm{M}$ LPA for $12 \mathrm{~h}$ after pretreated with indicated inhibitors $(10 \mu \mathrm{M}$ Ki16425, $100 \mathrm{ng} / \mathrm{mL}$ PTX and $100 \mathrm{nM}$ YM254890, a specific inhibitor of $\mathrm{G}_{\mathrm{q} / 11}$-proteins). The cell proliferation was measured by BrdU assay. Absorbance was read at $450 \mathrm{~nm}$ (690 $\mathrm{nm}$ as reference). $\mathbf{h}$ The cells in 24-multiplates were pretreated with $10 \mu \mathrm{M}$ PD98059 (an inhibitor of ERK1/2) for $30 \mathrm{~min}$ and incubated with $10 \mu \mathrm{M}$ LPA or $10 \mathrm{ng} / \mathrm{mL}$ PDGF for $48 \mathrm{~h}$, then detected by MTT. Values are means \pm SD and represent three independent experiments $(* \mathrm{p} \leq 0.05, * * \mathrm{p} \leq 0.01$ and $* * * \mathrm{p} \leq 0.001)$ 

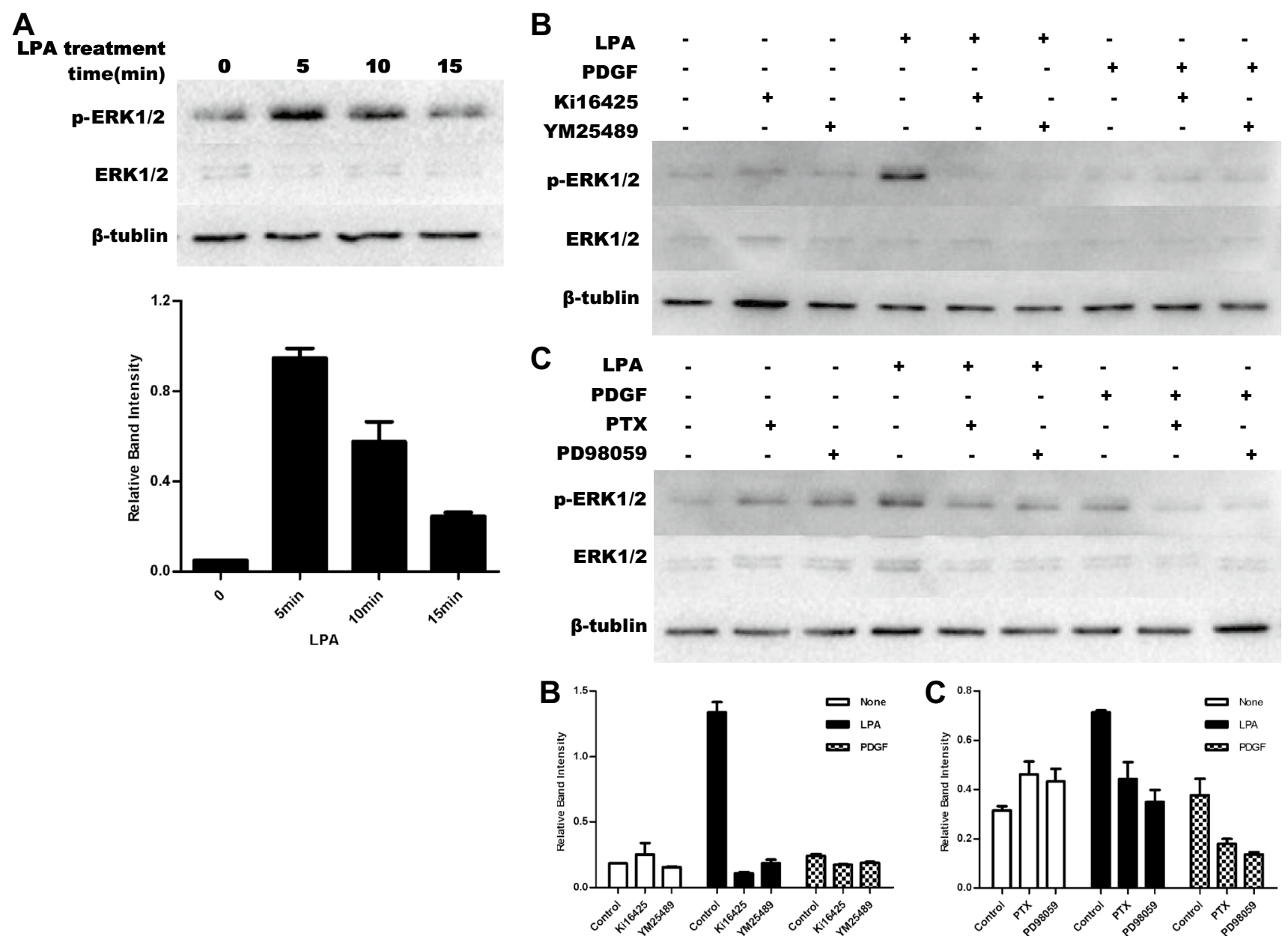

Fig. 5 LPA stimulated the proliferation of hUC-MSCs by LPAR1 mediated $\mathrm{G}_{\mathrm{i} / \mathrm{o}}$ and $\mathrm{G}_{\mathrm{q} / 11}$-proteins/ERK1/2 pathway. a HUC-MSCs were stimulated with $10 \mu \mathrm{M}$ LPA at the indicated time. The effects of LPA on ERK1/2 phosphorylation in hUC-MSCs were detected by western blot. b HUC-MSCs were stimulated with $10 \mu \mathrm{M}$ LPA for $5 \mathrm{~min}$ or $10 \mathrm{ng} / \mathrm{mL}$ PDGF for $10 \mathrm{~min}$ after pre-treated with or without $1 \mu \mathrm{M}$ Ki16425 for $15 \mathrm{~min}$ and $100 \mathrm{nM}$ YM254890 for $30 \mathrm{~min}$.

pathways when activated by LPA, such as PI3K-toAkt/PKB $\left(\mathrm{G}_{\mathrm{i} / \mathrm{o}}\right)$, Ras-to-ERK $\left(\mathrm{G}_{\mathrm{i} / \mathrm{o}}, \mathrm{G}_{\mathrm{q} / 11}\right)$ Rho $\left(\mathrm{G}_{12 / 13}\right)$, PLC-to-PKC $\left(\mathrm{G}_{\mathrm{q} / 11}\right)$ [20, 31, 43-45], Hippo-YAP pathway [46] and $\beta$-catenin pathway $[47,48]$ for pluripotency, cell survival, proliferation, differentiation/specification and migration. In our study, we found that PTX and PD98059, which are inhibitors of $\mathrm{G}_{\mathrm{i} / \mathrm{o}}$-protein and ERK1/2, respectively, completely inhibited the LPAinduced proliferation of hUC-MSCs. YM254890, a specific inhibitor of $\mathrm{G}_{\mathrm{q} / 11}$-proteins, has slightly effects on the LPA action. Meanwhile, LPA induced an increasing ERK1/2 phosphorylation, which was also significantly inhibited by pre-treatment of Ki16425, PTX, YM254890 and PD98059. These results showed that LPA stimulated the proliferation of hUC-MSCs through LPAR1/ $\mathrm{G}_{\mathrm{i} / \mathrm{o}}$ and $\mathrm{G}_{\mathrm{q} / 11} / \mathrm{ERK} 1 / 2$ pathway. Taken together, LPA
ERK1/2 phosphorylation were detected by western blot. c HUCMSCs were stimulated with $10 \mu \mathrm{M}$ LPA for $5 \mathrm{~min}$ after pre-treated with $100 \mathrm{ng} / \mathrm{mL}$ PTX for $16 \mathrm{~h}$ or $10 \mu \mathrm{M}$ PD98059 for $30 \mathrm{~min}$. ERK1/2 phosphorylation were detected by western blot. Values are means \pm SD and represent three independent experiments $(* \mathrm{p} \leq 0.05$, $* * \mathrm{p} \leq 0.01$ and $* * * \mathrm{p} \leq 0.001)$

suppressed LPS-induced caspase-3 activation, as returned by Ki16425 but not by PTX and YM254890. Interestingly, the caspase- 9 activity was increased by LPS significantly, but the caspase- 8 was hardly affected, then the both of caspases were not affected by LPA. Overall, these results indicated that LPA shown a anti-apoptosis action through decreasing the activation of caspase- 3 mediated by LPAR 1 coupled with $G$ proteins, but not $G_{i / o}$ or $G_{q / 11}$ in hUC-MSC.

\section{Conclusion}

LPA stimulated the proliferation of hUC-MSCs through LPAR $1 / \mathrm{G}_{\mathrm{i} / \mathrm{o}}$ and $\mathrm{G}_{\mathrm{q} / 1 /} / \mathrm{ERK} 1 / 2$ pathway. LPA shown a antiapoptosis action through LPAR1 mediated inhibition of 

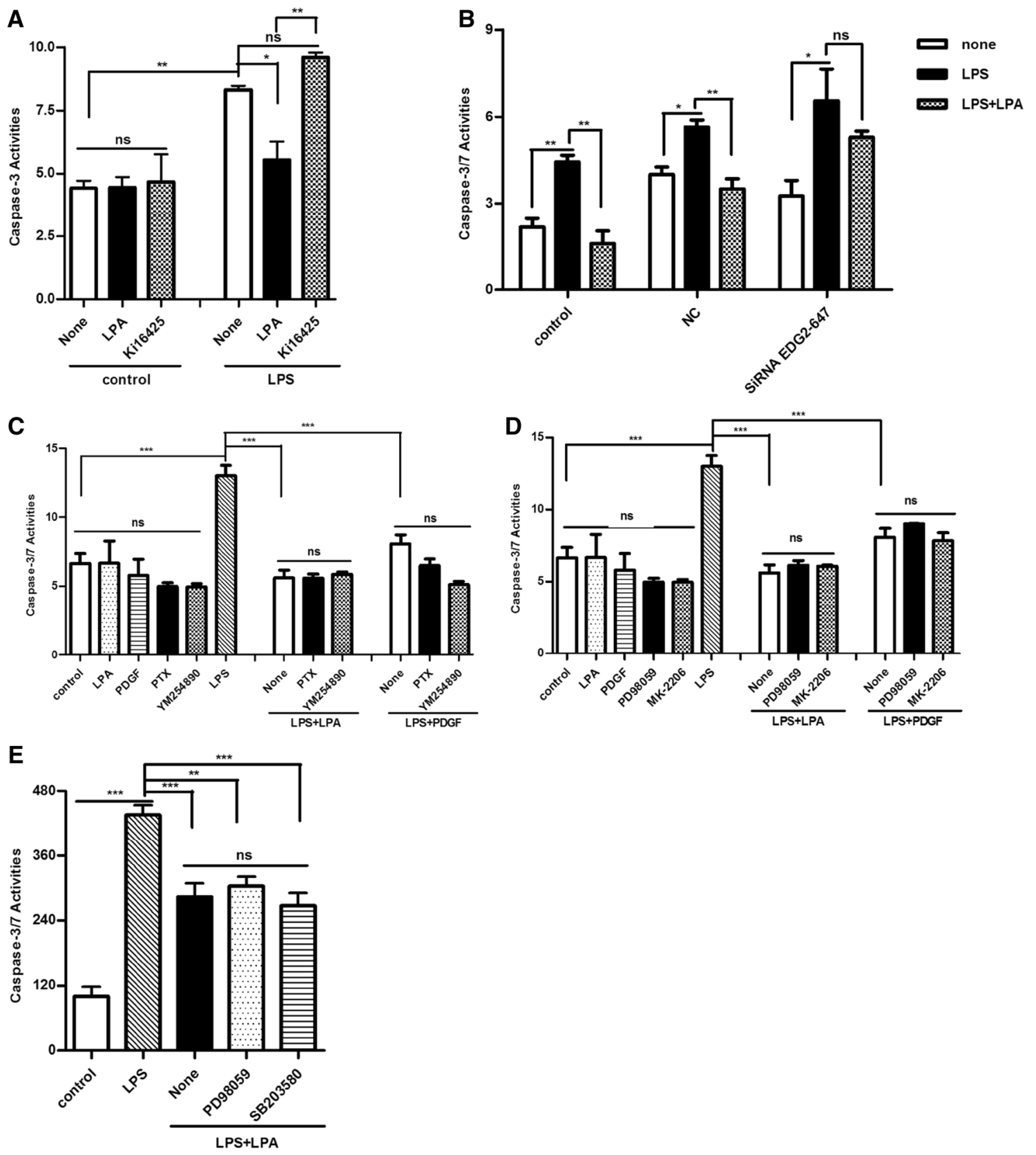

Fig. 6 LPA enhenced the survival of hUC-MSCs in PTX-independent manner. a HUC-MSCs in 96-multiplates were stimulated with $1 \mu \mathrm{M}$ LPA and $10 \mu \mathrm{g} / \mathrm{mL}$ LPS for $72 \mathrm{~h}$ after pretreated with or without $10 \mu \mathrm{M}$ Ki16425 for $30 \mathrm{~min}$. The caspase-3/7 activity was then detected. b HUC-MSCs in 96-multiplates were stimulated with $1 \mu \mathrm{M} \mathrm{LPA}$ and $10 \mu \mathrm{g} / \mathrm{ml}$ LPS for $24 \mathrm{~h}$ after transfected with $50 \mathrm{nM}$ NC siRNA (negative control) or LPAR1-specific siRNA EDG2homo-647 for $48 \mathrm{~h}$. The caspase-3/7 activity was then detected. c HUC-MSCs were stimulated with $1 \mu \mathrm{M}$ LPA and $10 \mu \mathrm{g} / \mathrm{mL}$ LPS for $24 \mathrm{~h}$ after pretreated with $100 \mathrm{ng} / \mathrm{mL}$ PTX for $16 \mathrm{~h}$ or $100 \mathrm{nM}$ YM254890 for $30 \mathrm{~min}$. The caspase-3 activity was examined by Apo-

$\mathrm{ONE}^{\circledR}$ homogeneous caspase-3/7 assay. d HUC-MSCs were stimulated with $1 \mu \mathrm{M}$ LPA and $10 \mu \mathrm{g} / \mathrm{mL}$ LPS for $24 \mathrm{~h}$ after pretreated with $10 \mu$ M PD98059 or $200 \mathrm{nM}$ MK-2206 (an inhibitor of Akt, Selleckchem) for $30 \mathrm{~min}$. The caspase-3 activity was examined by Apo$\mathrm{ONE}^{\circledR}$ homogeneous caspase-3/7 assay. e HUC-MSCs in 96-multiplates were stimulated by $10 \mu \mathrm{g} / \mathrm{mL}$ LPS and $1 \mu \mathrm{M}$ LPA for $24 \mathrm{~h}$ with or without indicated inhibitors $(10 \mu \mathrm{M}$ Erk1/2 inhibitor PD98059 and $10 \mu \mathrm{M}$ p38 MAP kinase inhibitor SB203580). The caspase-3 activity was detected by Apo-ONE ${ }^{\circledR}$ homogeneous caspase-3/7 assay. Values are means \pm SD and represent three independent experiments $(* \mathrm{p} \leq 0.05, * * \mathrm{p} \leq 0.01$ and $* * * \mathrm{p} \leq 0.001)$ 


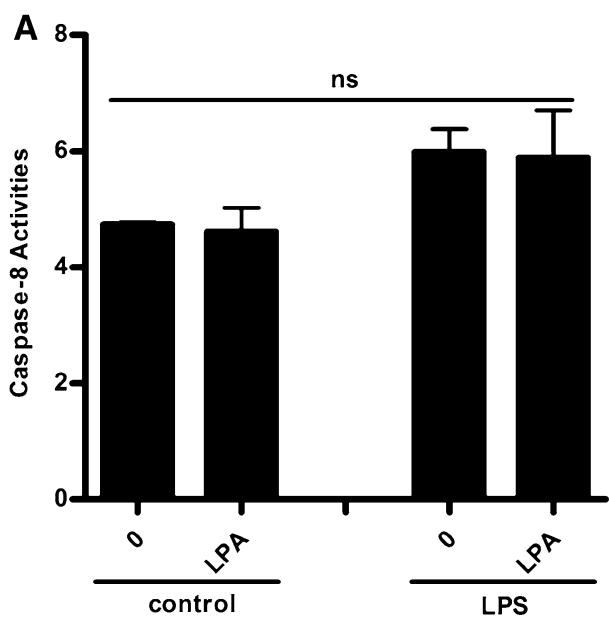

Fig. 7 LPA elicited anti-apoptotic effect by inhibiting caspase-3. a HUC-MSCs in 96-multiplates were incubated with $1 \mu \mathrm{M}$ LPA and $10 \mu \mathrm{g} / \mathrm{mL}$ LPS for $48 \mathrm{~h}$. The caspase- 8 activity was detected by Apo$\mathrm{ONE}^{\circledR}$ homogeneous caspase- 8 assay. b HUC-MSCs in 96-multi-

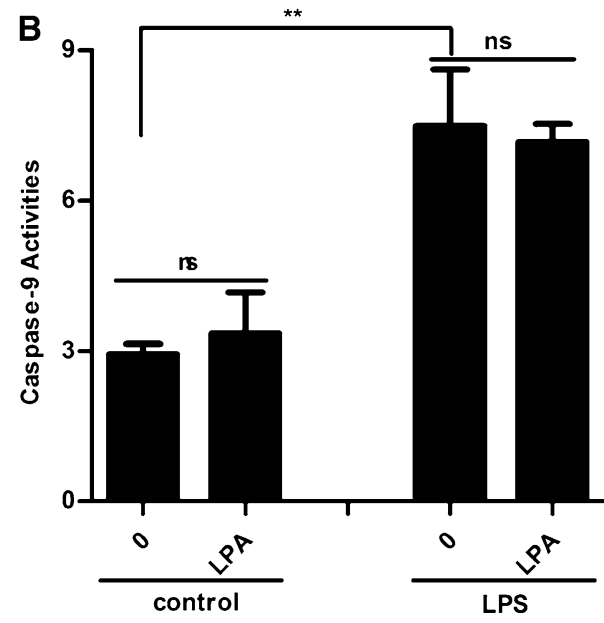

plates were incubated with $1 \mu \mathrm{M}$ LPA and $10 \mu \mathrm{g} / \mathrm{mL}$ LPS for $48 \mathrm{~h}$. The caspase- 9 activity was detected by Apo-ONE ${ }^{\circledR}$ homogeneous caspase- 9 assay. Values are means \pm SD and represent three independent experiments $\left(* \mathrm{p} \leq 0.05,{ }^{*} \mathrm{p} \leq 0.01\right.$ and $\left.* * * \mathrm{p} \leq 0.001\right)$

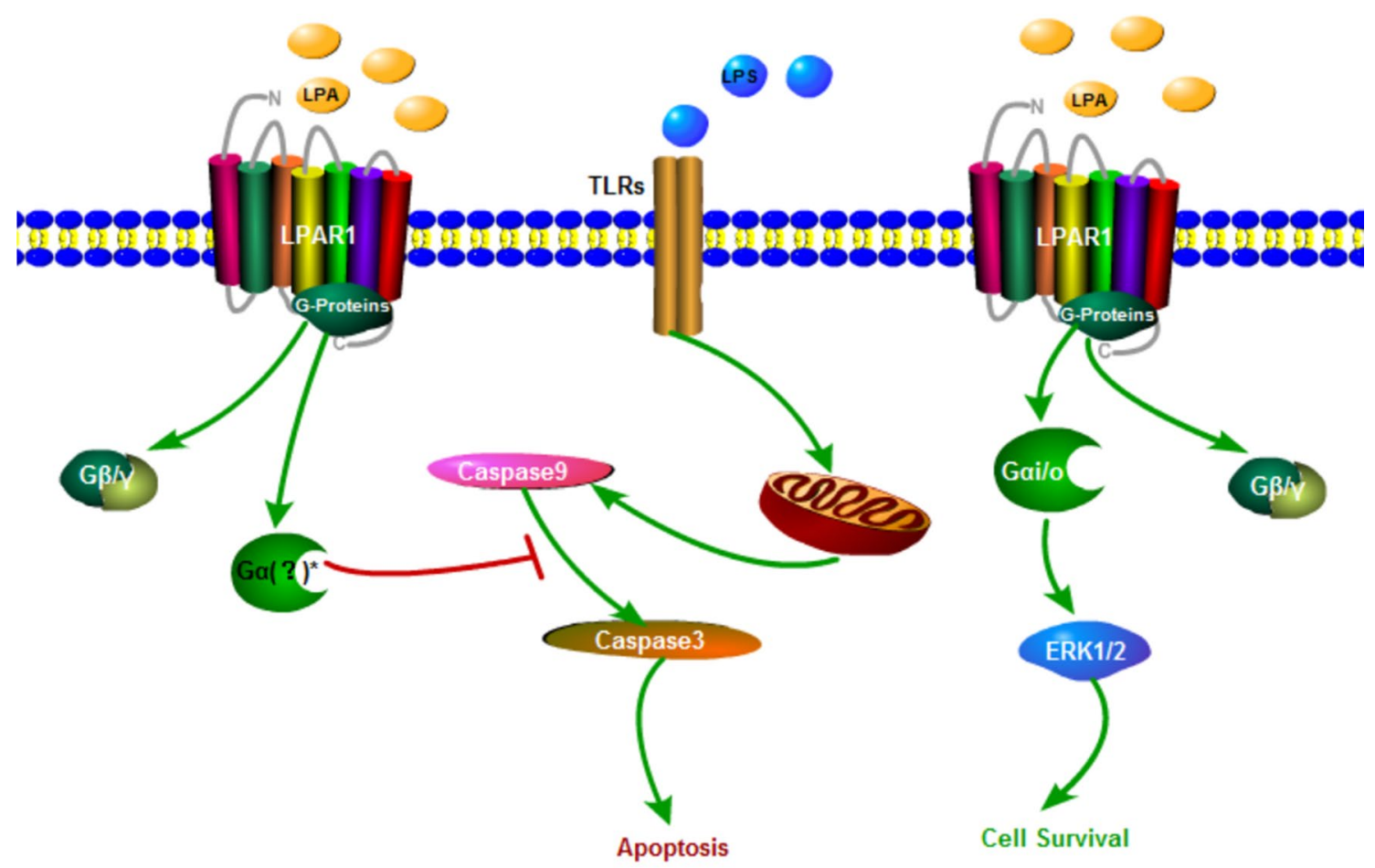

${ }^{\star}$ Note:Ga( ? ) is not Gai/o or Gaq/11.

Fig. 8 Conclusion pigture. LPA stimulated the proliferation of hUC-MSCs through LPAR1/Gi/o and Gq/11/ERK1/2 pathway. LPA shown a anti-apoptosis action through LPAR1 coupled with $\mathrm{Gx}$ (not Gi/o or Gq/11) mediating inhibition of caspase-3 activation in hUC-MSC

caspase-3 activation. Our results also shown that the $\mathrm{G}$ proteins coupled with LPAR1 were not $\mathrm{G}_{\mathrm{i} / \mathrm{o}}$ or $\mathrm{G}_{\mathrm{q} / 11}$ in hUCMSC (Fig. 8). More importantly, LPA have not induce the differentiation of hUC-MSC during expansion in vitro, which is required in cell therapy and tissue engineering.
Acknowledgements We are grateful to Prof. Fumikazu Okajima at Gunma University for a generous gift of the YM-254890.

Funding This study was funded by National Science Foundation of China (Nos. 81460021, 8166010065 and 31260210). 


\section{Compliance with ethical standards}

Conflict of interest The authors declare that they have no conflict of interest.

Informed consent Informed consent was obtained from all individual participants included in the study.

Open Access This article is distributed under the terms of the Creative Commons Attribution 4.0 International License (http:// creativecommons.org/licenses/by/4.0/), which permits unrestricted use, distribution, and reproduction in any medium, provided you give appropriate credit to the original author(s) and the source, provide a link to the Creative Commons license, and indicate if changes were made.

\section{References}

1. Turinetto V, Vitale E, Giachino C (2016) Senescence in human mesenchymal stem cells: functional changes and implications in stem cell-based therapy. Int J Mol Sci 17(7):1164

2. Afanasyev BV, Elstner E, Zander AR (2009) A.J. Friedenstein, founder of the mesenchymal stem cell concept. Cell Ther Transplant 1(3):35-38. doi:10.3205/ctt-2009-en-000029.01

3. Sangiorgi B, Panepucci RA (2016) Modulation of immunoregulatory properties of mesenchymal stromal cells by tolllike receptors: potential applications on GVHD. Stem Cells Int 2016(2016):1-10

4. Beer L, Mildner M, Gyöngyösi M, Ankersmit HJ (2016) Peripheral blood mononuclear cell secretome for tissue repair. Apoptosis 21(12):1336-1353

5. Crisan M, Yap S, Casteilla L, Chen CW, Corselli M, Park TS, Andriolo G, Sun B, Zheng B, Zhang L (2008) A perivascular origin for mesenchymal stem cells in multiple human organs. Cell Stem Cell 3(3):301-313

6. Dominici ML, Blanc KL, Mueller I, Slaper-Cortenbach I, Marini F, Krause D, Deans R, Keating A, Prockop D, Horwitz E (2006) Minimal criteria for defining multipotent mesenchymal stromal cells. The International Society for Cellular Therapy position statement. CytoTherapy 8(4):315-317

7. Sherman LS, Shaker M, Mariotti V, Rameshwar P (2017) Mesenchymal stromal/stem cells in drug therapy: new perspective. CytoTherapy 19(1):19

8. Hayflick L (1965) The limited in vitro lifetime of human diploid cell strains. Exp Cell Res 37(3):614-636

9. Wollert KC, Meyer GP, Lotz J, Ringes-Lichtenberg S, Lippolt P, Breidenbach C, Fichtner S, Korte T, Hornig B, Messinger D, Arseniev L, Hertenstein B, Ganser A, Drexler H (2004) Intracoronary autologous bone-marrow cell transfer after myocardial infarction: the boost randomised controlled clinical trial. Lancet 364(9429):141-148

10. Damirin A, Tomura H, Komachi M, Liu JP, Mogi C, Tobo M, Wang JQ, Kimura T, Kuwabara A, Yamazaki Y (2007) Role of lipoprotein-associated lysophospholipids in migratory activity of coronary artery smooth muscle cells. AJP Heart Circ Physiol 292(5):H2513-H2522

11. Komachi M, Damirin A, Malchinkhuu E, Mogi C, Tobo M, Ohta H, Sato K, Tomura H, Okajima F (2009) Signaling pathways involved in DNA synthesis and migration in response to lysophosphatidic acid and low-density lipoprotein in coronary artery smooth muscle cells. Vascul Pharmacol 50(5-6):178-184
12. Hecht JH, Weiner JA, Post SR, Chun J (1996) Ventricular zone gene-1 (vzg-1) encodes a lysophosphatidic acid receptor expressed in neurogenic regions of the developing cerebral cortex. J Cell Biol 135(4):1071-1083

13. Tanaka M, Okudaira S, Kishi Y, Ohkawa R, Iseki S, Ota M, Noji S, Yatomi Y, Aoki J, Arai H (2006) Autotaxin stabilizes blood vessels and is required for embryonic vasculature by producing lysophosphatidic acid. J Biol Chem 281(35):25822-25830

14. Schwab SR, Pereira JP, Matloubian M, Xu Y, Huang Y, Cyster JG (2005) Lymphocyte sequestration through S1P lyase inhibition and disruption of S1P gradients. Science 309(5741):1735-1739

15. Baker DL, Desiderio DM, Miller DD, Tolley B, Tigyi GJ (2001) Direct quantitative analysis of lysophosphatidic acid molecular species by stable isotope dilution electrospray ionization liquid chromatography-mass spectrometry. Anal Biochem 292(2):287-295

16. Shimizu T, Wolfe LS (1990) Arachidonic acid cascade and signal transduction. J Neurochem 55(1):1-15

17. Funk CD (2001) Prostaglandins and leukotrienes: advances in eicosanoid biology. Science 294(5548):1871-1875

18. Shimizu $T$ (2009) Lipid mediators in health and disease: enzymes and receptors as therapeutic targets for the regulation of immunity and inflammation. Pharmacol Toxicol 49(49):123-150

19. Ji WC, Lee CW, Chun J (2008) Biological roles of lysophospholipid receptors revealed by genetic null mice: an update. Biochim Biophys Acta (BBA) 1781(9):531-539

20. Ishii I, Fukushima N, Xiaoqin Ye A, Chun J (2004) Lysophospholipid receptors: signaling and biology. BioChemistry 73(73):321-354

21. Fukushima N, Ishii I, Contos JJ, Weiner JA, Chun J (2001) Lysophospholipid receptors. Annu Rev Pharmacol 41(41):507-534

22. Anliker B, Chun J (2004) Cell surface receptors in lysophospholipid signaling. Semin Cell Dev Biol 15(5):457-465

23. Ji WC, Herr DR, Noguchi K, Yun CY, Lee CW, Mutoh T, Lin ME, Teo ST, Park KE, Mosley AN (2010) LPA receptors: subtypes and biological actions. Pharmacol Toxicol 50(50):157-186

24. Davenport AP (2013) International union of basic and clinical pharmacology. LXXXVIII. G protein-coupled receptor list: recommendations for new pairings with cognate ligands. Pharmacol Rev 65(65):967-986

25. An S, Bleu T, Hallmark OG, Goetzl EJ (1998) Characterization of a novel subtype of human $\mathrm{G}$ protein-coupled receptor for lysophosphatidic acid. J Biol Chem 273(14):7906-7910

26. Bandoh K, Aoki J, Hosono H, Kobayashi S, Kobayashi T, Murakamimurofushi K, Tsujimoto M, Arai H, Inoue K (1999) Molecular cloning and characterization of a novel human G-protein-coupled receptor, EDG7, for lysophosphatidic acid. J Biol Chem 274(39):27776-27785

27. Noguchi K, Ishii S, Shimizu T (2003) Identification of p2y9/ GPR23 as a novel G protein-coupled receptor for lysophosphatidic acid, structurally distant from the Edg family. J Biol Chem 278(28):25600-25606

28. Lee CW, Rivera R, Gardell S, Dubin AE, Chun J (2006) GPR92 as a new G12/13- and Gq-coupled lysophosphatidic acid receptor that increases cAMP, LPA5. J Biol Chem 281(33):23589

29. Kotarsky K, Boketoft A, Bristulf J, Nilsson NE, Norberg A, Hansson S, Owman C, Sillard R, Leeb-Lundberg LMF, Olde B (2006) Lysophosphatidic acid binds to and activates GPR92, a $\mathrm{G}$ protein-coupled receptor highly expressed in gastrointestinal lymphocytes. J Pharmacol Exp Therapeut 318(2):619-628

30. Yanagida K, Ishii S (2011) Non-Edg family LPA receptors: the cutting edge of LPA research. J Biochem 150(3):223-232

31. Llona-Minguez S, Ghassemian A, Helleday T (2015) Lysophosphatidic acid receptor (LPAR) modulators: the current pharmacological toolbox. Prog Lipid Res 58:51-75 
32. Zhou H, Xu HHK (2011) The fast release of stem cells from alginate-fibrin microbeads in injectable scaffolds for bone tissue engineering. Biomaterials 32(30):7503-7513

33. Can A, Karahuseyinoglu S (2007) Concise review: human umbilical cord stroma with regard to the source of fetus-derived stem cells. Stem Cells 25(11):2886-2895

34. Yang D, Yang W, Zhang Q, Yan HU, Bao L, Damirin A (2013) Migration of gastric cancer cells in response to lysophosphatidic acid is mediated by LPA receptor 2. Oncol Lett 5(3):1048-1052

35. Chen J, Baydoun AR, Xu R, Deng L, Liu X, Zhu W, Shi L, Cong X, Hu S, Chen X (2008) Lysophosphatidic acid protects mesenchymal stem cells against hypoxia and serum deprivationinduced apoptosis. Stem Cells 26(1):135-145

36. Fukushima N, Kimura Y, Chun J (1998) A single receptor encoded by vzg-1/1pA1/edg-2 couples to G-proteins and mediates multiple cellular responses to lysophosphatidic acid (LPA). Proc Natl Acad Sci 95(11):6151-6156

37. Callihan P, Ali MW, Salazar H, Quach N, Wu X, Stice SL, Hooks SB (2014) Convergent regulation of neuronal differentiation and Erk and Akt kinases in human neural progenitor cells by lysophosphatidic acid, sphingosine 1-phosphate, and LIF: specific roles for the LPA1 receptor. Asn Neuro 6(6):1-18

38. Sun Y, Nam JS, Han DH, Kim NH, Choi HK, Lee JK, Rhee HJ, Huh SO (2010) Lysophosphatidic acid induces upregulation of Mcl-1 and protects apoptosis in a PTX-dependent manner in H19-7 cells. Cell Signal 22(3):484-494

39. Lee HJ, Ryu JM, Jung YH, Lee KH, Kim DI, Han HJ (2016) Glycerol-3-phosphate acyltransferase-1 upregulation by O-GlcNAcylation of $\mathrm{Sp} 1$ protects against hypoxia-induced mouse embryonic stem cell apoptosis via mTOR activation. Cell Death Dis 7(3):e2158
40. Kostic I, Fidalgocarvalho I, Aday S, Vazão H, Carvalheiro T, Grãos M, Duarte A, Cardoso C, Gonçalves L, Carvalho L (2015) Lysophosphatidic acid enhances survival of human CD34(+) cells in ischemic conditions. Sci Rep 5:1-18

41. Binder BY, Genetos DC, Leach JK (2014) Lysophosphatidic acid protects human mesenchymal stromal cells from differentiation-dependent vulnerability to apoptosis. Tissue Eng A 20(7-8):1156-1164

42. Wang XY, Fan XS, Cai L, Liu S, Cong XF, Chen X (2015) Lysophosphatidic acid rescues bone mesenchymal stem cells from hydrogen peroxide-induced apoptosis. Apoptosis 20(3):273-284

43. Bieberich E (2012) It's a lipid's world: bioactive lipid metabolism and signaling in neural stem cell differentiation. Neurochem Res 37(6):1208-1229

44. Dorsam RT, Gutkind JS (2007) G-protein-coupled receptors and cancer. Nat Rev Cancer 7(2):79-94

45. Abdelwahid E, Kalvelyte A, Stulpinas A, Guarita-Souza LC, Foldes G (2016) Stem cell death and survival in heart regeneration and repair. Apoptosis 21(3):252

46. Yu FX, Zhao B, Panupinthu N, Jewell JL, Lian I, Wang LH, Zhao J, Yuan H, Tumaneng K, Li H, Fu XD, Mills GB, Guan KL (2012) Regulation of the hippo-YAP pathway by G-proteincoupled receptor signaling. Cell 150(4):780-791

47. Badri L, Lama VN (2012) Lysophosphatidic acid induces migration of human lung-resident mesenchymal stem cells through the $\beta$-catenin pathway. Stem Cells 30(9):2010-2019

48. Ryu JM, Han HJ (2015) Autotaxin-LPA axis regulates hMSC migration by adherent junction disruption and cytoskeletal rearrangement via LPAR1/3-dependent PKC/GSK3 $\beta / \beta$-catenin and PKC/Rho GTPase pathways. Stem Cells 33(3):819-832 